\title{
EAST ASIAN STUDIES IN LATIN AMERICA AND ITS POTENTIAL CONTRIBUTIONS FOR AN IMPROVED INTER-REGIONAL BUSINESS UNDERSTANDING
}

\author{
Yunuen Ysela Mandujano-Salazar* \\ https://orcid.org/0000-0003-4794-6584
}

RECIBIDO: Mayo 2021 / ACEPTADO: Julio 2021 / PUBLICADO: Septiembre 2021

\begin{abstract}
Como citar: Mandujano-Salazar, Yunuen. (2021). East asian studies in latin america and its potential contributions for an improved inter-regional business understanding. Telos: revista de Estudios Interdisciplinarios en Ciencias Sociales, 23 (3), Venezuela. (Pp. 710-727).

DOI: www.doi.org/10.36390/telos233.13
\end{abstract}

\section{ABSTRACT}

East Asia is today one of the most powerful regions worldwide in terms of innovation, economic and industrial growth. And as such, it has taken its business models, industrial processes, and technology to Latin America, notoriously increasing economic relations. However, Latin American countries have been mostly on the recipient side, perhaps because there is a limited understanding of their Asian counterparts. East Asian Studies provide important knowledge for Latin American specialists on economics and business, improving Latin American business theory, models, and economic relations between regions. Following Michel Foucault's ideas about the archeological method to understand the context in which a discipline is born, this article follows documentary research and summarizes the similarities and differences between the economic contexts of these regions at the beginning of the Cold War and at the beginning of the 21 st century to establish the relevance for understanding East Asian economic and business models. Then, it reconstructs the development of East Asian Studies as an academic area worldwide and its standing in Latin America, highlighting how the political and economic context has influenced its emergence and topics of research. Finally, it reflects on the contributions that can reciprocally be made between the East Asian studies in Latin America and a Latin American School of Business Thought.

Keywords: Asian Studies; Latin America-East Asia relations; Asian economic models; Asian business models.

\footnotetext{
* Profesora-investigadora del Departamento de Ciencias Sociales de la Universidad Autónoma de Ciudad Juárez. Licenciada en Economía, Maestría en Estudios de Asia y África especialidad Japón y doctorado en Ciencias Sociales. Miembro del Sistema Nacional de Investigadores Nivel 1. Profesora asociada del Korea Foundation E-school Program para América Latina, en donde imparte cursos sobre cultura y política económica japonesa. Lineas de investigación: Identidades y vida cotidiana; discursos hegemónicos y medios de comunicación; estudios japoneses. Email: yunuen.mandujano@uacj.mx
} 


\section{Estudios de Asia oriental en América Latina y sus posibles contribuciones para una} mejor comprensión empresarial interregional

\section{RESUMEN}

El Este de Asia es actualmente una de las regiones más poderosas del mundo en términos de innovación y crecimiento económico e industrial. De tal forma, ha trasladado sus modelos de negocios, sus procesos industriales y su tecnología a América Latina, incrementando notablemente las relaciones interregionales. Sin embargo, los países latinoamericanos se han mantenido mayormente en el lado receptor, quizá debido a que existe un limitado conocimiento de las contrapartes asiáticas. Los estudios asiáticos, en específico del Este de Asia, proveen información y conocimiento importante para los especialistas latinoamericanos en economía y negocios, el cual puede apoyar a la mejora de la teoría y modelos de negocios latinoamericanos, así como a las relaciones entre regiones. Siguiendo las ideas del método arqueológico de Michel Foucault a fin de comprender el contexto en el que nace una disciplina, este artículo parte de una investigación documental y sintetiza las similitudes y diferencias entre los contextos económicos de estas regiones al comienzo de la Guerra Fría y al inicio del siglo XXI, a fin de establecer la relevancia de la comprensión de los modelos económicos y de negocios del este de Asia. Después, reconstruye el desarrollo de los estudios asiáticos como un área de conocimiento en el mundo y su posición en América Latina, resaltando cómo el contexto políticoeconómico ha influencia su surgimiento y temas de investigación. Finalmente, reflexiona sobre las contribuciones mutuas que pueden realizarse entre los estudios del Este de Asia en América Latina y una Escuela de pensamiento de negocios latinoamericana.

Palabras clave: Estudios asiáticos; relaciones América Latina-Asia; modelos económicos asiáticos; modelos de negocios asiáticos.

"Science (or what is offered as such) is localized in a field of knowledge and plays a role in it. A role that varies according to different discursive formations, and is modified with their mutations."

-Michel Foucault, The Archeology of Knowledge

\section{Introduction}

In 1998, the United Nations Economic Commission for Latin America published a report on the perspectives of the commercial relations between Latin America and Pacific Asia-or East Asia-highlighting the relevance of improving information exchange, institutions, and technical and economic cooperation to facilitate access to markets and business development (NU CEPAL Unidad de Comercio Internacional, 1998). Two decades later, researchers for the Inter-American Development Bank were calling Latin American \& Caribbean political and private sector leaders to implement more proactive policies and strategies, looking at Asia as a crucial region for commercial exchange. As the share of trade with Asia had gone from 9\% in 2000 to $26 \%$ in 2018; however, Latin America continued missing significant opportunities for diversified business development (Giordano \& Ortiz de Mendívil, 2019). 
East asian studies in latin america and its potential contributions for an improved inter-regional business understanding

Nowadays, East Asia is one of the most powerful and dynamic regions worldwide in terms of innovation, economic and industrial growth. As such, it has taken its business models, industrial processes, and technology to Latin America, notoriously increasing economic and business relations. Nevertheless, Latin American nations have been mostly on the recipient side, remaining largely as buyers of Asian products or as markets of cheap labor for Asian-capital corporations that come to the region. Regardless of regional and international organisms constantly inviting Latin American leaders and entrepreneurs to exploit the opportunities that Asia can mean as a market for products and investment, perhaps because there is a limited cultural understanding, not much has changed, and the Asian side is essentially the one obtaining major benefits from the trade agreements and economic relations with this region. Unfortunately, a considerable indifference towards Asia is also reflected in the Latin American business academic sphere, wherein is limited awareness about Asian policies, economic and business models, and culture, which are key to doing fruitful business with those countries.

In this context, and inspired by what Michel Foucault (1972) called the archaeological method, this article followed documentary research and analysis of academic sources and historical reports from international economic organisms to find research focused on Asia and the history of Asian Studies in the world and in Latin America, as well as the socioeconomic and political context in which originated and the debates in which they got involved at critical points in its history. A total of sixty-three documents were revised, and fifty-seven were considered to provide relevant information to trace the development of Asian Studies, as the other six were redundant. These were found through eleven academic databases and search engines containing Humanities and Social Sciences documents-i.e., ArchiveGrid, CiNii, Google Scholar, JSTOR, EBSCO Research Database, Library of Congress, National Diet Library Collection, Project MUSE, SciELO, Redalyc, and WorldCat. Also, through a search on the internet for official Websites of European, North, and Latin American superior education institutions with centers or programs dedicated to the study of East Asia, twenty-seven institutions were identified. Still, only twenty provided some historical data about their origins. All this information allowed to rebuild the contextual conditions in which East Asian Studies emerged and developed, so its potential contributions for a Latin American School of Business Thought could be argued.

First, the article summarizes the key similarities and differences between the economic contexts of Latin America and East Asia regions at the beginning of the Cold War and, six decades later, at the beginning of the $21^{\text {st }}$ century. Then, it reconstructs the most relevant elements in the development of East Asian studies as an academic area in the world and its standing in Latin America, highlighting how the political and economic context has influenced its emergence and topics of interest. Finally, building on personal experiences as a Latin American scholar of East Asian Studies, I reflect on the contributions that can reciprocally be made between this discipline and a Latin American School of Business Thought and the potential impacts of overlooking them.

\section{Latin America and East Asia: convergence and divergence}

After World War II, the new political and economic order divided the world into three blocks: the capitalist economies led by the United States, the communist and socialist states, and the nations that were considered to have comparable circumstances at the time-an experience 
of colonization or dependence, a nonexistent or incipient industrialization model, and a poor economy. Many labels have been used and debated to identify them, but First, Second and Third world, and developed and under-developed/developing/emerging nations became common during the Cold War. These terms, with all their ambiguity and overlapping, were not empty of meaning: they were used by international organizations, politicians, and even scholars to symbolize the inequality of power in the global order, so they have been heavily criticized for denoting a hierarchy in which Western-a term with its own problematic discourse-and capitalist societies were put as the ultimate cultural and economic model for all nations (Holm, 1990; Huntington, 1993; Olopade, 2014; Randall, 2004; Said, 2003; Willems, 2014).

During the Cold War, Latin American and many East and Southeast Asian nations were frequently classified as Third World, under-developed, developing, emerging countries, or other similar labels that implied a low rank in their global economic and political status. This is because, at the beginning of this period, they seemed to share the burden and hopes that came with being in the process of finding their way to a wealthier and more prosperous position. However, by the end of the $20^{\text {th }}$ century, many Asian nations were no longer developing or emerging. They had experienced so-called economic miracles—high and sustained rates of economic growth-that translated in high-quality infrastructure, high levels of education, better living conditions for their population, and relative political stability (Ito \& Weinstein, 1996).

In 1950, a report of the United Nations Economic Commission for Latin America (1950) declared that the region had promising conditions to improve: Latin American countries had not been devastated by World War II; many had even benefited from supplying goods to the allies during the war; most had achieved their freedom from European colonizers more than a century before, so they had relatively autonomous political systems; and, they were rich in natural resources and workforce. These nations relied mostly on exporting agriculture and low-tech manufacturing products, so the report emphasized the importance of promoting the region's technical progress and industrialization to improve productivity. Nevertheless, it highlighted that merely supplanting successful models of great economic centers was not the answer; it called for a better understanding of the region's specific economic, social, demographic, and political circumstances in the new post-war world order.

In contrast, a year later, the Economic Commission for Asia and the Far East (1951) noted that Asia was in a more difficult position. After the end of World War II, most countriesexcept the Korean Peninsula, which was in a sort of civil war-showed improvement compared to their conditions in 1945. Yet, most had suffered not only the devastation due to war but also critical changes in their political institutions and economic models; some had been freed from colonial control, while others-like Japan-were forced to change their governance structure drastically to comply with peace treaties. That meant not only economic but also political and social challenges faced while the countries had the urgency to rebuild their infrastructure and provide food and basic products to their starving populations. In 1950, even Japan, which was the one showing the best signs of economic recovery, had not yet achieved its pre-war production levels in many basic agricultural and industrial goods; also, there was increasing inflation along the region, which threatened to impact people who were recovering their stable incomes negatively. In general, "poverty was widespread in the region during the colonial and immediate post-war periods" (Economic and Social Commission for Asia and the Pacific, 2014, p. 37). 
East asian studies in latin america and its potential contributions for an improved inter-regional business understanding

East Asian and South Asian nations were a strategic region during the Cold War period, with some nations allied with the capitalist and some with the socialist block. Allies of the United States, as Japan and, eventually, South Korea, Taiwan, and Hong Kong, profited from becoming providers of goods and materials needed by troops in conflict regions such as the Korean Peninsula and Vietnam; they also avoided some military costs as the United States maintained military bases in many allied territories. On the other hand, most of Latin America had not such a critical role and, as such, was not as benefited by the United States and other allied nations.

Fast-forward to the turn of the century, and most Latin American countries were dealing with financial crisis originated for performing - for decades-as "experimental lab[s] of economic policies" (Aizenman, 2005, p. 959). Inflation, poverty, inequality, external debt, dependency on foreign money, low international competitiveness, and the dependence on agricultural, mineral, and low technology exports had not improved in those decades (Naim \& Lozada, s/f). Hofman (2000) analyzed the performance of Latin America during that half-century and concluded that having started the period better than East Asian countries, it had performed far worse. He found that, in 1950, Latin America's per capita real income was three times higher than in East Asia; however, by 1994, per capita, real income was about half of the average of East Asian countries. ${ }^{1}$ Also, the inequality measured by Gini coefficients did not change in five decades and remained higher than in East Asia. ${ }^{2} \mathrm{He}$ considered that one of the most important factors for this poor outcome was Latin America's development strategy based on import substitution and, after the 1980s crisis, on the exports of primary products and low-tech manufactures, all of which did not incentivize industry, agriculture, nor technological development enough.

On the other hand, during those decades, East Asian economies based their development strategy on industrial policies to build a strong industrial infrastructure with innovation as a key factor to improve their total factor productivity, allocating better quality resources where needed. High capital investment was important, but this was possible mainly due to the focus on the improvement of health, nutrition, educational levels of the population, and the emphasis on national technological research and innovation. That increased the overall quality of labor input, having positive effects on the performance of East Asian economies during the period (Economic and Social Commission for Asia and the Pacific, 2014; Hofman, 2000; Ito \& Weinstein, 1996; Lee \& Kim, 2018).

In 2010, some Latin American economists assessed the economic development of the region after two centuries since the beginning of the Independence wars along the region (Soto \& Zurita, 2011). They questioned the reasons why, after almost two hundred years, most Latin American economies had slow growth, substantial wealth inequality, and a pervading economic and political instability. In contrast, East Asian economies had conquered successful development in two or three decades, regardless of facing an external and internal financial and political crisis. They concluded that the key problems in Latin America were low productivity and

\footnotetext{
1 In 1950, the average per capita GDP (in international 1980 US dollars) was 29 in Latin America, 8 in Korea and Taiwan, 17 in Japan. By 1994, in Latin America was 28, in Korea and Taiwan 45, and in Japan 80. (Hofman, 2000, p. 33). Productivity 2 In 1950, the average Gini coefficient for Latin America was 0.510; in 1970, it was 0.518; and, in 1990, it was 0.506. On the other hand, in 1970, Korea had a 0.351; Japan, in 1969, had a 0.335; Taiwan, in 1959, had a 0.396. (Hofman, 2000, pp. 1617).
} 
the wrong policy choices-always following guidelines from Washington-while East Asian countries had been able to select adequate industrial policies or had been able to correct them, so, regardless of external shocks, those nations had found growth.

Latin America was a promising economic region in the mid-20th century; it certainly had better conditions than countries like Japan, the Republic of Korea, Vietnam, Singapore, or China. Nevertheless, fast-forward to the beginning of the $21^{\text {st }}$ century, Latin America did not advance substantially, and the region kept dealing with the same old problems. Latin American leaders, guided by scholars and specialists educated mostly in American and European universities, continue following the policies and models imposed by the so-called global North, even after decades of bad results. Thus, Latin American scholars, politicians, and entrepreneurs could benefit from knowledge about East Asia to enhance commercial relations with that region. From understanding those countries' development strategies and business models, not to reproduce them-because their cultural, social, and political realities are completely different-but to appreciate other realities, theories, and key elements that need to be improved in the region.

\section{From Oriental to East Asian Studies}

Throughout his work, but particularly in The Archeology of Knowledge, Foucault (1972) unveiled how certain systems of thought-epistemes-and discursive formations-knowledgeemerge and change, reflecting the dominant cosmovision of a particular era and context. This section presents the modest result of an effort to do archeology on the type of knowledge about Asia that has been generated by non-Asian academia. As Krarup (2021) argues, archaeology seeks the conditions of existence, maintenance, modification, or even disappearance of a system of thought. East Asian Studies, intrinsically interdisciplinary, evolved from what was known for decades as Oriental Studies, which emerged in the $19^{\text {th }}$ century in Europe as a tool of colonialism. During the Cold War, specialized studies on Asia appeared in Latin America, with rapid growth in the last three decades, when economic relations with Asia became relevant. Following Foucault, it is possible to explore the development and topics of interest of the discipline currently known as East Asian Studies and explore what it reveals in Latin America's current context.

Since the Enlightenment, knowledge and science have been synchronized in the public discourse as ways to reach a new level of prosperity for humanity. Although this utopic idea has been debunked by many critical thinkers, showing that science and knowledge have been tools serving power elites (Deleuze, 1999; Foucault, 1972, 1980; Horkheimer, 2002), there is no doubt that, since the Industrial Revolution, nations that have been successful in their economic development have been those able to identify which areas of knowledge need to be nurtured to contribute with the State aims. This was the case with the origin of the studies about Asia.

During the $19^{\text {th }}$ and first half of the $20^{\text {th }}$ century, European colonialist campaigns motivated the emergence of Oriental Studies, particularly in Great Britain. Through these, European nations, positioning themselves as the center of the world, propagated a discourse that labeled Europe as the Occident, the West, and everything from the Arab world to Japan was regarded as the Orient, the East: exotic, underdeveloped, and a threat to modernity and Christian values, justifying the intrusion in Asia (Said, 1985, 2003). Europe did not see Asia as an equal or as a military or industrial threat; it was a region to extract wealth. Nonetheless, Europeans needed to communicate and understand their cosmovision to extract the most benefit from those 
East asian studies in latin america and its potential contributions for an improved inter-regional business understanding

unfamiliar nations. As a result, Oriental Studies appeared in all European nations with colonialist campaigns and, relying heavily on Philology, focused on studying Asian languages, literature, and religion. This knowledge allowed Europe to build a discourse intended to "manage-and even produce-the Orient politically, sociologically, militarily, ideologically, scientifically, and imaginatively" (Said, 2003, p. 3).

Courses on so-called Middle and Far East languages, literature, religions, political systems, and history were taught in the most prestigious European universities since the $19^{\text {th }}$ century. In the United States, Yale also began teaching a few language and literature courses about the Far East (Council on East Asian Studies, 2018). However, during this first stage of development, the United Kingdom, as the leading colonialist nation, led the research and publication of scholarly material on the Orient through specialized faculties in Cambridge, the University of London, ${ }^{3}$ and Oxford. ${ }^{4}$

During World War II, the studies about Asia entered a new stage. For Allies, knowledge about enemies and the cultures of territories in dispute was essential. In the United Kingdom, a Commission of Enquiry into the Facilities for Oriental, Slavonic, East European and African Studies was established to analyze the production and needs of institutes dedicated to these studies (Evans \& Bevin, s/f). As a result, through the Scarborough Commission, many existing institutes received financial support, and others were created (Brown, 2016).

On the other hand, the United States, on the road to becoming the new leading nation of the capitalist democratic world, began promoting the study of Asia as part of its security and war strategies. Prominent American sociologists, anthropologists, diplomats, and political sciences scholars were asked by the government to study Japan-their enemy-and China and Korea-the nations in dispute (Benedict, 2003; Gerhardt, 1999). In 1958, the United States Congress passed the National Defense Education Act (NDEA), which allocated financial resources to encourage the expansion and improvement of academic programs that met critical national needs, among which were understanding various aspects of Asian societies (United States Senate, 1957). Strengthened by the Higher Education Act of 1965, more Asian Studies Centers and Institutes were established in important American universities in the following years, for example: the East Asian National Resource Center administered by Stanford, which became independent in 1975; the Weatherhead East Asian Institute of Columbia-established in 1949which became a National Resource Center in 1960; in 1961, the Center for Chinese Studies was established at the University of Michigan; in 1964, the University of Washington founded the East Asia Center; the Japan Institute at Harvard University - renamed the Reischauer Institute of Japanese Studies ${ }^{5}$ in 1985; and, in 1978, Berkeley established its own Institute of East Asian Studies. ${ }^{6}$

Thus, between the 1940s and 1960s, East Asian Studies appeared around all the prestigious American universities. Dissimilar to the focus on Humanities of the Oriental Studies developed in Europe, American Asian Studies were more oriented to the Social SciencesEconomics, Sociology, Political Science, Cultural Anthropology-and International Relations.

\footnotetext{
${ }^{3}$ See Web page: http://www.soas.ac.uk/about/history

${ }^{4}$ See Web page: http://orinst.web.ox.ac.uk/history-faculty-1

${ }^{5}$ See Web page: http://rijs.fas.harvard.edu/about-us

${ }^{6}$ See Web page: http://ieas.berkeley.edu/ieas-home/about-ieas/history-ieas
} 
Because of this, their main goal was to provide current information about enemies and potential allies for American intelligence agencies, bureaucrats, politicians, and big corporations, which supported the new academic field through foundations that gave research grants to strategic topics (Cumings, s/f).

Since the end of the Cold War, globalization and regionalization have become two seemingly contradictory but complementary trends in international economic and political relations. In Business Studies literature, a central topic has been the convergence or divergence of management and business strategies and practices across nations and regions. In this context and as a consequence of the progressively more evident presence and relevance of Asian capital and corporations worldwide, a new trend began in East Asian Studies around the developed nonAsian world institutions: they are increasingly intersecting with Business Studies. Many Business specialists and East Asian researchers have been interested in comparing Asian business and employment systems inside and outside those countries.

Most studies try to understand how Asian business and corporate models adapt to the global arena, what elements remain treasured in those nations, and what can be learned from them (Conrad, 2014; Hamilton \& Biggart, 1988; Heugens, Essen \& Oosterhout, 2009; Mathews, 2006; Steier, 2008). This research interest also intersects with the literature about varieties of capitalism (Lee, 2020; Tipton, 2008). In 2009, the Asia Pacific Journal of Management of Springer issued a special number on varieties of Asian capitalism, indigenization, and internationalization, and the editors highlighted the need for mainstream business and economy scholars in the West to study and understand complex institutional dynamics of Asian capitalism in the raising of the global influence of Asian economies and firms (Carney, Gedajlovic \& Yang, 2009).

This background and practical need for research on Asian businesses have pushed non-Asian universities in the developed nations to create hybrid academic programs of Asian Studies with an emphasis on business. The aim seems to be to improve the understanding of Asia to maximize the turnover from these nations' relations with the Asian countries. Some examples of programs that are active in 2021 are: the Business Administration-Global Business with East Asian Studies Concentration program of Hamline University, ${ }^{7}$ the Asian Studies Business Administration combined Bachelor and Master programs of St. John's University, ${ }^{8}$ the East Asian Business Studies program of the University of Alberta, ${ }^{9}$ the School of East Asian Studies of The University of Sheffield, ${ }^{10}$ the dual MA in East Asian Studies and Business Administration of Indiana University Bloomington, ${ }^{11}$ and the Joint MBA/MA in East Asian Area Studies of University of Southern California. ${ }^{12}$

\section{The emergence and struggles of East Asian Studies in Latin America}

On the other hand, in Latin America, East Asian Studies have had a less vigorous development. Until the end of World War II, some Latin American and East Asian nations held diplomatic relations, and countries such as Mexico, Peru, and Brazil had important Japanese, Korean and/or Chinese diasporas. Nevertheless, Latin American academic institutions had not

\footnotetext{
${ }^{7}$ See Web page: http://www.hamline.edu/business/global-business-east-asian-studies/

${ }^{8}$ See Web page: http://www.stjohns.edu/academics/programs/asian-studies-business-administration-bachelor-artsmaster-business-administration

${ }_{9}^{9}$ See Web page: http://apps.admissions.ualberta.ca/programs/bc/bc010/easst1

${ }^{10}$ See Web page: http://www.sheffield.ac.uk/seas/why-east-asia

${ }^{11}$ See Web page: $\underline{\text { http://ealc.indiana.edu/graduate/masters/dual.html }}$

${ }^{12}$ See Web page: http://dornsife.usc.edu/eascenter/joint-mba-ma/
} 
East asian studies in latin america and its potential contributions for an improved inter-regional business understanding

officially pursued the study of Asia. However, in1956, the United Nations Educational, Scientific and Cultural Organization (UNESCO) launched a call for a better cultural understanding and cooperation between West and East through the East-West Major Project (Havet, 1958). This would promote serious and intensive study on different cultures through some initial funding (Roger Riviere, 1967). This project meant the globalization of Asian Studies. Programs and institutes dedicated to studying Asian countries began appearing in Oceania, Asia itself, and Latin America, but the focus of the studies changed according to the country and time.

The first stage of Asian Studies in Latin America began when El Colegio de Mexicoone of Mexico's most prestigious Social Sciences and Humanities Research Centersresponded to the call from UNESCO, establishing a Section of Oriental Studies in its Center of International Studies in $1960 .{ }^{13}$ By 1966, an academic journal of Oriental Studies was launched, and, in 1968, a Center of Oriental Studies Asia was established focusing on history, religion, literature, and languages. In 1967, the Universidad del Salvador in Argentina founded the first School of Oriental Studies in South America, teaching history, literature, religions, and philosophy. ${ }^{14}$

As it can be noticed, not only the names but also the curricula of these programs followed the European model. However, contrary to the case of Europe, the reasoning behind choosing to focus on Humanities was not clear. Studying Asian ancient history, languages, and literature in post-war Latin America seemed to respond to the personal interests of the scholars involved in the project and not to a national strategic plan or vision about what to do with that knowledge.

Also, around the world, the critical academic discourse of the 1960s and 1970s, and the famous book Orientalism by Edward Said (2003), accused the colonial background of Oriental studies and the hierarchy that the term Oriental implied. Thus, El Colegio de Mexico and many European Oriental Studies Faculties dropped the term and changed their names to refer to a continent, subcontinent, or country in specific. In the case of El Colegio de México, in 1974, it changed the title of its journal to Studies of Asia and Africa and, in 1975, the name of its center to Center of Asian and North African Studies, which, eventually, became the Center of Asian and African Studies. Nevertheless, the emphasis on Humanities continued, although current political and social topics were added.

In 1976, as few other educational institutions in the region developed some form of programs about Asia and/or Africa, the Latin American Association of Asian and African Studies (ALADAA) was established. ${ }^{15}$ This, however, did not serve to spread the knowledge about Asia in Latin American academic circles of specialized disciplines. Although, at that stage, most scholars were, in fact, Historians, Anthropologists, Sociologists, etc., as they began specializing in Asia or Africa, they presented their work in this incipient community.

In 1980, the Pacific Economic Cooperation Council (PECC) was established as a partnership of representatives from business, industry, government, and scholars from eleven countries of the Asia Pacific region, aimed to promote economic cooperation and market integration; no Latin American country was represented (Pacific Economic Cooperation Council,

\footnotetext{
${ }^{13}$ See Web page: http://ceaa.colmex.mx/ceaa/historia

${ }^{14}$ See Web page: http://fleo.usal.edu.ar/fleo carrera-estudios-orientales

${ }^{15}$ See Web page: http://www.aladaainternacional.com/2018/10/sobre-aladaa/
} 
2009). In 1989, the Asia-Pacific Economic Cooperation (APEC) was established by twelve Asia Pacific economies, including the two most powerful at the time - the United States and Japanand other rapidly growing ones-such as Korea, Indonesia, Malaysia, Singapore, Thailand, and Philippines (Asia-Pacific Economic Cooperation, 2020).

Meanwhile, most Latin American countries were suffering a financial crisis, partly due to their reliance on the United States market and economic guidance. In such a context, Latin American governments began noticing the importance of expanding their trade and seeking commercial treaties and alliances with Asia, but there was a general lack of knowledge about those countries. Responding to the specific need to understand East Asian economies and seek trade with them, some Latin American scholars from economic, business, and international relations began to focus on the East Asian region. Eventually, some universities launched programs or centers specialized in East Asian studies, focusing not on classical literature, religion, and history but economics, politics, business, and contemporary society and culture, marking an evolution of this discipline in Latin America. Although there were still some cases of orientalist programs in Latin America-such as the one of the Pontifical Catholic University of Peru, which, in 1988, opened a Center of Oriental Studies ${ }^{16}$-by the end of the 1980s, Asian Studies in Latin America would enter a second stage.

In 1988, Miguel de la Madrid-then Mexican president-established the Mexican Commission of the Pacific (Comisión Mexicana de la Cuenca del Pacífico), intended to get Mexico accepted into the PECC. Some members were from the University of Colima. Consequently, in 1989, this university started a program of interdisciplinary studies about the Pacific region; in 1990, along with other Mexican universities, it created the National Network of Researchers on the Pacific; and in 1998, the Center of Studies APEC was opened. ${ }^{17}$

Mexico joined the APEC in 1993, and, since then, some other Mexican universities have established their own programs or centers dedicated to East Asia. In 2006, the Center of Asian Studies opened in the Autonomous University of Nuevo León. ${ }^{18}$ In 2012, the Autonomous University of Nayarit received support from the South Korean embassy to establish a King Sejong Institute to promote the Korean language and eventually opened a program of Korean Studies, which has had difficulties remaining opened (Observatorio Universitario, 2017). In 2013, the National Autonomous University of Mexico created a Seminar on Asian Studies, which evolved, in 2017, to the University Program of Asian and African Studies. ${ }^{19}$ In 2016, the University of Guadalajara established a Center of Japanese Studies to teach Japanese language and serve as connection for exchanges with Japanese universities (Ríos, 2016).

Chile joined the APEC in 1994. In 1996, the Pontifical Catholic University of Chile formed an Asian Studies Program that evolved, in 2011, to the UC Center for Asian Studies intended to deepen interdisciplinary and international cooperation with Asia. ${ }^{20}$ In 2005, the Catholic University of the Santísima Concepción also established a Center of Studies and

\footnotetext{
${ }^{16}$ See Web page http://www.pucp.edu.pe/unidad/centro-de-estudios-orientales/

${ }_{17}$ See Web page http://portal.ucol.mx/cueicp2/historia.htm\#historia

${ }^{18}$ See Web page http://cea.uanl.mx/centro-de-estudios-asiaticos/

${ }^{19}$ See Web page http://pueaa.unam.mx/

${ }^{20}$ See Web page http://estudiosasiaticos.uc.cl/acerca-del-centro/presentacion
} 
East asian studies in latin america and its potential contributions for an improved inter-regional business understanding

Development Pacific Asia to promote cultural languages and commercial exchange between Chile and Asia. ${ }^{21}$

Peru joined the APEC in 1998. In 2013, the University of the Pacific opened the Center of Peru-China Studies. And in 2017, it changed its name to include Asia Pacific with the goal to generate strategic knowledge and a long-term perspective about Asia Pacific region in terms of economic development, markets, and international relations. ${ }^{22}$ In 2018, the University of San Marcos opened its Center of Asian Studies focused on economics and international relations with Korea, China, India, and Japan. ${ }^{23}$

The mentioned countries and programs do not constitute a complete list but reflect how the contextual demands of the nations have pushed the emergence of the discipline and its emphasis on certain topics and discourses. However, contrary to the cases of Europe, Australia, Canada, and the United States, in which the establishment of programs and institutes has been encouraged and supported by governments, in Latin America, the launching of East Asian Studies programs has been mostly an effort from individual scholars or university bureaucrats who have understood the relevance of expanding the knowledge about Asian counterparts aspotential-commercial partners, aiming to increase this awareness in their countries. Contrary to the elitist first-generation programs of Oriental Studies in Latin America, those that have appeared to focus on economic and business topics aim to reach other disciplines, to make other scholars notice the importance of looking to Asia.

Unfortunately, many projects have failed to remain active because the support received institutionally or through national governments is minimal or due to overwhelming centralism that keeps access to founding and academic cooperation among institutions mostly nonexistent. For example, in the case of Mexico, major academic institutions with Asian-related programs are concentrated in the country's central region. Staffed by senior scholars from the first generations of graduates on Asian Studies in Latin America, they rarely collaborate with younger scholars from peripherical universities and keep debating the same topics as decades before.

In this sense, centralism and elitism among scholars have been important obstacles for developing and consolidating a Latin American School of East Asian Studies. Although an increasing number of young Latin American specialists in East Asian Studies has been graduating in the last two decades, due to the scarcity of stable academic programs in the region and to the frequent preference for foreign scholars, they have difficulties finding positions to pursue their careers as researchers on Asian topics.

This situation is not specific to Latin America, though; on the contrary, it is a recurrent problem in area studies worldwide. Because of the importance of an advanced comprehension of the language and culture of a particular country, many new Area Studies programs prefer to hire native people from the area of specialization - who may not even have a formation on Area Studies-than hiring young non-native scholars who have studied about it. As a result, many of the novice Latin American graduates of East Asian Studies end up moving to other professions, or, if they can find an opportunity - which is also hard to find for Latin Americans-they move to

\footnotetext{
${ }^{21}$ See Web page http://cedap.ucsc.cl/descripcion-e-historia/

22 See Web page http://www.up.edu.pe/investigacion-centros/centros-up/centro-estudios-china-asiapacifico/Paginas/acerca-del-centro.aspx

${ }^{23}$ See Web page http://vrip.unmsm.edu.pe/centro-de-estudios-asiaticos-unmsm/
} 
Asia to work in academia. However, most of the time, it is as a Latin American Spanish specialist, not for their academic background, but their nationality. The few who can secure a position in a Latin American academic institution that does not have an East Asian Studies program must work between fields to keep their research alive.

And, since there is a funding lack and steady programs specialized in East Asian Studies in Latin America, many scholars must look for external financial support, typically is found through Asian embassies and agencies dedicated to the promotion of their countries worldwidee.g., The Japan Foundation, The Korea Foundation, The Confucius Institute, etc. That means that instead of being the Latin American countries the ones funding research on Asia for their own agendas, as is the case in developed nations regarding Area Studies, in this case, Asian countries are the ones funding studies about them in Latin America. Therefore, the support and resources available are part of Asian nations' soft power policies and depend on whether the research topic from a Latin American scholar or the focus of study from a particular Latin American academic program is of interest for the Asian country-this is if it enters in its own agenda. Nonetheless, this situation has opened many opportunities to consolidate an East Asian Studies School of Taught and the business taught in Latin America.

\section{East Asian Studies intersecting Business Thought in Latin America}

As it was argued before, East Asian countries have surpassed Latin America, and some have become leading economies with powerful innovation and business models. There is a lot to learn from them. However, Latin American entrepreneurs, bureaucrats, politicians, and specialists in Business and Economics rarely look to East Asia for examples, inspiration, or even for markets; whether they do, they seldom try to understand them in their whole cultural and social context. Thereby, they frequently fail when they implement a model in Latin America or negotiate with Asian counterparts.

And, while Latin America remains greatly indifferent to them, East Asian businesses have been increasing their presence in Latin America. In the $21^{\text {st }}$ century, as trade agreements between Asian and Latin American nations have been signed, Japanese, Korean, Chinese, Taiwanese, and other East Asian corporations have been appearing around Latin America. As a result, Asian governments have been providing more funding to academic programs and scholars expected to help expand proper knowledge for their capitals to flourish, boosting studies focused on economic, industrial, and business topics.

This has meant that, particularly in the last decade, Latin American scholars on East Asian Studies have focused their research and contributions to understanding East Asian development and cultural models, trying to find the key reasons for their success. That is generating an important body of information on East Asia and Latin America economic relations. However, the most robust is generated from an international relations point of view, which has been a critical factor in how diplomatic relations, trade agreements, and economic zones positively impact the region and/or particular countries in Latin America. But because in these countries, there is a low interest in exploiting the relations with Asia, many opportunities are being lost (Balderrama Santander, 2017; Bavoleo, 2020; Busilli, 2020; Falck Reyes, 2016; Infante Jiménez et al., 2018; Quintero Sánchez, 2020; Razumovsky, 2014).

A few others are presented from a more practical Business standpoint and analyze particular sectors or industries' processes and production networks in Latin America as they are 
East asian studies in latin america and its potential contributions for an improved inter-regional business understanding

reshaped by Asian investment or models (Amparo Tello, Contreras Teodoro \& Serrano Camarena, 2020 Guzmán Anaya, 2019; López Aymes \& Morales Fajardo, 2018; Santiago Mendoza et al., 2019). Some others center on explaining East Asian industrial policies, innovation and business models for the use of Latin American Business and Economy experts (Cervera Jiménez, 2011; Lemus Delgado, 2020; Mandujano-Salazar, 2020; Santiago Mendoza et al., 2019; Valencia Lomelí, 2021).

\section{As a final consideration: The potential contributions of East Asian Studies to a Business Thought in Latin America}

East Asian Studies is an interdisciplinary area, and as such, scholars tend to specialize in a country, and a certain topic, rather than producing theory; their goal is to grasp the social, cultural, economic, and political context of a country or region to understand a particular phenomenon. One of the aims of many recent generations of Latin American East Asian Studies scholars has been to disseminate case-centered knowledge for easier access to the Latin American public and the building of collaborative networks in the region that may support a paradigm change. In this sense, many of us are looking to collaborate not only with other East Asian Studies specialists but also with scholars from diverse critical areas of study-such as Business and Economics-to exchange experiences and knowledge.

In this sense, research programs and academic courses sponsored by Asian governments have been crucial to expanding the understanding of successful East Asian economic, industrial, and business models among Latin American scholars and students of relevant knowledge areas. Throughout my career as a Japanese Studies researcher, I have received diverse grants from the Japan Foundation through its Japanese Language and Japanese Studies Fellowship Programs, which have allowed the production of numerous articles that have inserted in the current regional and global debates on Japanese Studies. Also, as an Associate Professor of the Korean Foundation E-School Program, I have witnessed the impact that online courses about Japanese, Chinese and Korean economy, industrial policy, and corporate culture have had to reach more than a dozen universities around Latin America.

Also, academic journals born from second-stage East Asian programs have an important emphasis on publishing research about Asian business, innovation, and economic policies, and about cases of Latin America-East Asia commercial exchange that can contribute to expanding the vision of Latin American scholars nonspecialized on Asia. Journals, such as México y la cuenca del Pacífico, ${ }^{24}$ PORTES, revista mexicana de estudios sobre la Cuenca del Pacifico, ${ }^{25}$ or Mundo Asia Pacifico, ${ }^{26}$ are not limited to East Asia Studies specialists, but gather much of the research about East Asia that can prove of interest to those trying to connect Latin America with the Asian region.

Thus, East Asian Studies in Latin America have been slowly expanding in the last couple of decades, in the context of a growing economic interest of Asia in our region. Although classical knowledge of the then-called Oriental Studies remains part of the topics being explored,

\footnotetext{
${ }^{24}$ See Web page of México y la Cuenca del Pacífico: http://www.mexicoylacuencadelpacifico.cucsh.udg.mx/index.php/mc

${ }^{25}$ See Web page of PORTES: www.portesasiapacifico.com.mx/index.php

${ }^{26}$ See Web page of Mundo Asia Pacífico: publicaciones.eafit.edu.co/index.php/map
} 
there is more emphasis on the analysis of East Asian economic, industrial, business development, contemporary culture and society, and Asian business insertion in Latin America.

In this context, the collaboration and building of networks with Latin American Economics and Business specialists are crucial. As it was mentioned above, the United States, Europe, and other so-called developed regions are creating programs that focus both on Business and East Asia; they have understood that Asian economic and business models cannot be fully grasped by Western theories, and there is a need to understand them if there is an intention to maximize opportunities in the economic relations with those countries. Unfortunately, the theoretical knowledge that tends to dominate within Latin American scholars in most areas derives from the hegemonic global North. Still, more than half century of limited success has shown that the models derived from it are not entirely useful and productive for Latin American reality.

In the middle of the Fourth Industrial Revolution, it is essential Latin American scholars must acknowledge the need for a paradigm change. Whether they continue overlooking the importance of understanding Asian economic and business models, there is little hope of improvement, as vigorous emerging Asian nations are the direct competitors of many Latin American countries in the global market. The study of Asia can provide business opportunities, clues on how to build models for the specific contexts and needs of our region, and how to face them as competition. Latin American East Asian Studies, Economics, and Business scholars should collaborate and advance not only theoretical and methodological proposals, unique for Latin America, but also promote the improvement of Latin American and Asian economic relationships to expand the possibilities of business for our region.

\section{Bibliographic references}

Aizenman, Joshua. (2005). Financial Liberalisations in Latin America in the 1990s: A Reassessment. The World Economy, 28(7). (Pp.959-983). https://doi.org/10.3386/w11145

Amparo Tello, Dagoberto; Contreras Teodoro, Ana Belén; Serrano Camarena, Diana Elena. (2020). Reconfiguración de las redes productivas en la industria de la joyería en Thrissur, India, Chantaburi, Tailandia y Guadalajara, México. PORTES, revista mexicana de estudios sobre la Cuenca del Pacífico, 14(28), México. (Pp. 221-247). Extraído de http://www.portesasiapacifico.com.mx/?p=articulo\&id $=400$

Asia-Pacific Economic Cooperation. (2020). History. APEC Asia-Pacific Economic Cooperation. Extraído de www.apec.org/About-Us/About-APEC/History

Balderrama Santander, Renato. (2017). Corea del Sur en el marco de la economía del conocimiento y una nueva estrategia de cooperación con México en el 55 aniversario de relaciones diplomáticas. México y la Cuenca del Pacífico, 6(18), México. (Pp. 9-16). Extraído de: www.scielo.org.mx/pdf/mcp/v6n18/2007-5308-mcp-6-18-00009.pdf

Bavoleo, Bárbara I. (2020). TIC y gobierno electrónico. Cooperación entre Corea del Sur y América del Sur. PORTES, revista mexicana de estudios sobre la Cuenca del Pacífico, 14(28), México. (Pp. 125-144). Extraído de http://www.portesasiapacifico.com.mx/?p=articulo\&id=396

Benedict, Ruth. (2003). El crisantemo y la espada. Alianza Editorial. España.

Brown, lan. (2016). The great post-war expansion. En Brown, lan (editor). The School of 
East asian studies in latin america and its potential contributions for an improved inter-regional business understanding

Oriental and African Studies. Cambridge University Press. Gran Bretaña. https://doi.org/10.1017/CBO9781316687208.005

Busilli, Virginia Soledad. (2020). La Economic Statecraft de China en América Latina y el rol de las asociaciones estratégicas. El Caso de la relación China-Argentina. PORTES, revista mexicana de estudios sobre la Cuenca del Pacífico, 14(28), México. (Pp. 57-78). Extraído de http://www.portesasiapacifico.com.mx/index.php?p=articulo\&id=393

Carney, Michael; Gedajlovic, Eric; Yang, Xiaohua. (2009). Varieties of Asian capitalism: Toward an institutional theory of Asian enterprise. Asia Pacific Journal of Management, 26, Estados Unidos. (Pp. 361-380). https://doi.org/10.1007/s10490-009-9139-2

Cervera Jiménez, José Antonio. (2011). Ciencia, Innovación y Desarrollo Económico en Asia Oriental: lecciones para América Latina. Revista gestión de las personas y tecnología, 10. (Pp. 44-53). Extraído de https://dialnet.unirioja.es/descarga/articulo/4120948.pdf

Conrad, Harald. (2014). Continuity and Change in Asian Employment Systems: A Comparison of Japan, South Korea, and Taiwan. En Wilkinson, Adrian; Degg, Geoffrey (editores). The Oxford Handbook of Employment Relations. (Pp. 334-358). Oxford University Press. Gran Bretaña.

Council on East Asian Studies. (2018). A Brief History of East Asian Studies at Yale University.

Yale Council of East Asian Studies. Extraído de https://ceas.yale.edu/about-ceas/briefhistory-east-asian-studies-yale-university

Cumings, Bruce. (s/f). Boundary Displacement: Area Studies and International Studies during and after the Cold War. Extraído de www.mtholyoke.edu/acad/intrel/cumings2.htm

Deleuze, Gilles. (1999). Conversaciones 1972-1990. Pre-textos. España.

Economic and Social Commission for Asia and the Pacific. (2014). Asia and the Pacific: A Story of Transformation and Resurgence. Extraído de www.unescap.org/sites/default/files/Asia and the Pacific-A Story of Transformation and Resurgence.pdf

Economic Commission for Asia and the Far East. (1951). Economic Survey of Asia and the Far East 1950. Extraído de www.unescap.org/sites/default/d8files/knowledgeproducts/Economic survey of Asia and the Far East 1950.pdf

Economic Commission for Latin America. (1950). The Economic Development of Latin America.

Extraído de www.rrojasdatabank.info/prebisch theec-development.pdf

Evans, Benjamin Ifor; Bevin, Ernest. (s/f). Commission of Enquiry into the Facilities for Oriental, Slavonic, East European and African Studies. JISC Archives Hub. Extraído de https://archiveshub.jisc.ac.uk/search/archives/54575010-b851-3a02-98e3-c3ca981aed16

Falck Reyes, Melba E. (2016). Red de inversión japonesa en México. México y la Cuenca del

Pacífico, 5(14), México. (Pp. 13-17). https://doi.org/10.32870/mycp.v5i14.504

Foucault, Michel. (1972). The Archeology of Knowledge. Pantheon Books. Estados Unidos.

Foucault, Michel. (1980). Power/Knowledge. Selected Interviews and Other Writings 19721977. Pantheon Books. Estados Unidos.

Gerhardt, Uta. (1999). A world from brave to new: Talcott Parsons and the war effort at Harvard University. Journal of The History of the Behavioral Sciences, 35(3), Estados Unidos. (Pp. $\quad$ 257-289). $\quad$ https://doi.org/10.1002/(sici)1520-6696(199922)35:3<257::aidjhbs5>3.0.co;2-a

Giordano, Paolo; Ortiz de Mendívil, Cloe. (2019). Making the most of connectivity: unlocking 
the trade potential of Latin America and the Caribbean in Asia. Inter-American

Development Bank. https://doi.org/10.18235/0001598

Guzmán Anaya, Leo. (2019). Knowledge Transfer in the Automotive Industry: The Case of JICA's

Project for Automotive Supply Chain Development in Mexico. México y la Cuenca del

Pacífico, 8(23), México. (Pp. 93-122). https://doi.org/10.32870/mycp.v8i23.609

Hamilton, Gary G.; Biggart, Nicole W. (1988). Market, Culture, and Authority: A Comparative

Analysis of Management and Organization in the Far East. American Journal of

Sociology, 94, Estados Unidos. (Pp. 52-94). https://doi.org/10.1086/228942

Havet, Jacques. (1958). UNESCO's East-West Major Project. The UNESCO Courier, 11(12),

Francia. (Pp. 20-21). Extraído de https://unesdoc.unesco.org/ark:/48223/pf0000066947

Heugens, Pursey, Essen, Marc van; Oosterhout, J Hans van. (2009). Meta-analyzing ownership

concentration and firm performance in Asia: Towards a more fine-grained understanding.

Asia Pacific Journal of Management, 26, Estados Unidos. (Pp. 481-512). DOI: https://doi.org/10.1007/s10490-008-9109-0

Hofman, Andre A. (2000). The Economic Developmen of Latin America in the Twentieth

Century. Edward Elgar. Estados Unidos. Extraído de repositorio.cepal.org/bitstream/handle/11362/1650/S33098H713E_en.pdf?sequence=1\&i sAllowed=y

Holm, Hans-Henrik. (1990). The end of the Third World? Journal of Peace Research, 27(1), Estados Unidos. (Pp. 1-7). Extraído de www.jstor.org/stable/423769

Horkheimer, Max. (2002). Crítica de la razón instrumental. Editorial Trotta. España.

Huntington, Samuel P. (1993). The Clash of Civilizations? Foreign Affairs, 72(3), Estados Unidos. (Pp. 22-49). DOI: https://doi.org/10.2307/20045621

Infante Jiménez, Zoe T.; Ortega Gómez, Priscila; Ortiz Paniagua, Carlos Francisco. (2018). La inserción de México al TPP como estrategia para potencializar el comercio y las inversiones. México y la Cuenca del Pacífico, 7(21), México. (Pp. 121-143) DOI: https://doi.org/10.32870/mycp.v7i21.537

Ito, Takatoshi; Weinstein, David E. (1996). Japan and the Asian Economies: A "Miracle" in

Transition. Brookings Papers on Economic Activity, 1996(2), Estados Unidos. (Pp. 205-272). DOI: https://doi.org/10.2307/2534622

Krarup, Troels. (2021). Archaeological Methodology: Foucault and the History of Systems of Thought. Theory, Culture \& Society, 0(0), Gran Bretaña. (Pp. 1-22). DOI: https://doi.org/10.1177/0263276420984528

Lee, Keun. (2020). Varieties of capitalism and rethinking the East Asian model. DOC Research Institute. Extraído de https://doc-research.org/2020/09/varieties-capitalism-rethinkingeast-asian-model/

Lee, Keun; Kim, Yee-Kyoung. (2018). Comparing the National Innovation Systems in East Asia and Latin America: Fast vs Slow. En Lee, Keun; Kim, Yee-Kyoung. Innovation in the Asia Pacific. Springer Singapure. Singapur. DOI: https://doi.org/10.1007/978-981-10-58950_3

Lemus Delgado, Daniel Ricardo. (2020). Vietnam: políticas públicas en ciencia, tecnología e innovación. Estudios de Asia y África, 55(2), México. (Pp. 263-294). DOI: https://doi.org/10.24201/eaa.v55i2.2454

López Aymes, Juan Felipe; Morales Fajardo, María Esther. (2018). Engagement to Global 
East asian studies in latin america and its potential contributions for an improved inter-regional business understanding

Production Networks in Southeast Asia: Prospects for Technology Upgrade and Lessons for Latin America. México y la Cuenca del Pacífico, 7(20), México. (Pp. 21-63). DOI: https://doi.org/10.32870/mycp.v7i20.547

Mandujano-Salazar, Yunuen Ysela. (2020). Revisitando el modelo de la cultura corporativa japonesa y la importancia de su comprensión en América Latina. NovaRUA. Revista Universitaria de Administración, 12(21), México. (Pp. 82-104). DOI: https://doi.org/10.20983/novarua.2020.21.5

Mathews, John A. (2006). Dragon Multinationals: New players in $21^{\text {st }}$ century globalization. Asia Pacific Journal of Management, 23, Estados Unidos. (Pp. 5-27). DOI: 10. https://doi.org/1007/s10490-006-6113-0

Naim, Moises; Lozada, Carlos. (s/f). Latin America's Economics: The Good, The Bad, And The Ugly. Extraído de www.carnegieendowment.org/pdf/files/latinamericaneconomics.pdf

NU CEPAL Unidad de Comercio Internacional. (1998). Perspectivas del comercio entre América Latina y Asia y el Pacífico. Comisión Económica para América Latina y el Caribe. Extraído de www.cepal.org/es/publicaciones/30939-perspectivas-comercio-america-latina-asiapacifico

Observatorio Universitario. (2017). Observatorio Universitario. Facebook. Extraído de www.facebook.com/observatoriouan/posts/1254671031306554?comment_id=12555495 04552040

Olopade, Dayo. (2014). The End of the "Developing World". The New York Times. Extraído de https://www.nytimes.com/2014/03/01/opinion/sunday/forget-developing-fat-nations-mustgo-lean.html

Pacific Economic Cooperation Council. (2009). Introduction \& History. PECC Pacific Economic Cooperation Council. Extraído de www.pecc.org/about/pecc-introduction-and-history

Quintero Sánchez, Adelina. (2020). China frente a EE. UU. en la evolución del régimen internacional de inversiones en Asia-Pacífico. PORTES, revista mexicana de estudios sobre la Cuenca del Pacífico, 14(28), México. (Pp. 31-55). Extraído de www.portesasiapacifico.com.mx/index.php? $p=$ articulo\&id $=392$

Randall, Vicky. (2004). Using and Abusing the Concept of the Third World: Geopolitics and the Comparative Political Study of Development and Underdevelopment. Third World Quarterly, 25(1), Reino Unido. (Pp. 41-53). Extraído de www.jstor.org/stable/3993776

Razumovsky, Dmitry. (2014). América Latina y Asia Oriental. Iberoamérica, 1, Rusia. (Pp. 532). Extraído de www.ilaran.ru/pdf/2014/lberoamerica/lA 2014 1/Razumovsky.pdf

Ríos, Julio. (2016). Crean el Centro de Estudios Japoneses del CUCSH. Universidad de Guadalajara. Extraído de www.udg.mx/es/noticia/crean-el-centro-de-estudios-japonesesdel-cucsh

Roger Riviere, Juan. (1967). El "Proyecto Mayor" Oriente-Occidente de la UNESCO. Boletín de la Asociación Española de Orientalistas, 3, Francia. (Pp. 7-16). Extraído de repositorio.uam.es/handle/10486/6295

Said, Edward W. (1985). Orientalism Reconsidered. Cultural Critique, 1, Estados Unidos. (Pp. 89-107). https://doi.org/10.2307/1354282

Said, Edward W. (2003). Orientalism. Penguin Books. Estados Unidos.

Santiago Mendoza, Mario Alberto; Zottele Allende, Anibal Carlos; Méndez Viveros, Claudia Eliú; 
Sánchez Guevara, Miriam. (2019). Pymes, e-commerce y equidad de género. Tópicos en el marco de APEC. PORTES, revista mexicana de estudios sobre la Cuenca del Pacífico, 13(26), México. (Pp. 7-26). Extraído de www.portesasiapacifico.com.mx/index.php? $p=$ articulo\&id $=374$

Soto, Raimundo; Zurita, Felipe. (2011). Two centuries of economic growth: Latin America at its bicentennial celebration. Latin American Journal of Economics, 48(2), Chile. (Pp. 113132). Extraído de https://scielo.conicyt.cl/scielo.php?pid=S0719$04332011000200001 \&$ script $=$ sci_abstract

Steier, Lloyd P. (2009). Familial capitalism in global institutional contexts: Implications for corporate governance and entrepreneurship in East Asia. Asia Pacific Journal of Management, 26, Estados Unidos. (Pp. 513). https://doi.org/10.1007/s10490-008-9117-0 Tipton, Frank B. (2009). Southeast Asian capitalism: History, institutions, states, and firms. Asia Pacific Journal of Management, 26, Estados Unidos. (Pp. 401-434). https://doi.org/10.1007/s10490-008-9118-z

United States Senate. (1957). Sputnik Spurs Passage of the National Defense Education Act. United States

Senate. Extraído de www.senate.gov/artandhistory/history/minute/Sputnik_Spurs_Passage_of_National_Def ense_Education_Act.htm\#: :text=The National Defense Education Act of 1958 became one of,and private colleges and universities.

Valencia Lomelí, Enrique. (2021). Empresarios y régimen de bienestar: el caso de Corea del Sur. México y la Cuenca del Pacífico, 10(28), México. (Pp. 35-70). https://doi.org/10.32870/mycp.v10i28.722

Willems, Wendy. (2014). Beyond Normative Dewesternization: Examining Media Culture from the Vantage Point of the Global South. The Global South, 8(1), Reino Unido. (Pp. 7-23). https://doi.org/10.2979/globalsouth.8.1.7 